\title{
Water flux in boreal forest during two hydrologically contrasting years; species specific regulation of canopy conductance and transpiration
}

\author{
Emil Cienciala $^{a *}$, Jiri Kucera ${ }^{b}$, Michael G. Ryan ${ }^{\mathrm{c}}$, \\ Anders Lindroth ${ }^{\mathrm{d}}$
}

\author{
"Department of Soil Sciences, Swedish University of Agricultural Sciences, \\ Box 7014, 75007 Uppsala, Sweden \\ ${ }^{b}$ Laboratory of Environmental Measuring Systems, Turisticka 5, 62100 Brno, Czech Republic \\ ${ }^{c}$ Rocky Mountain Experiment Station, USDA Forest Service, Fort Collins, CO, USA \\ ${ }^{\mathrm{d}}$ Department for Production Ecology, Swedish University of Agricultural Sciences, \\ Box 7042, 75007 Uppsala, Sweden
}

(Received 15 January 1997; accepted 21 October 1997)

\begin{abstract}
We estimated the reduction of transpiration from drought for tree species in a mixed boreal 60-year-old stand in central Sweden. Actual transpiration was estimated from direct measurements of sap flow rate in Pinus sylvestris and Picea abies trees during two consecutive years with contrasting precipitation. Drought-induced reduction of transpiration (transpiration deficit) was quantified as the difference between the measured sap flow and the transpiration calculated for non-limiting soil water conditions. The drought-free transpiration was estimated on an hourly basis from Penman-Monteith equation with the parameterized canopy conductance $\left(g_{\mathrm{c}}\right)$ functions for individual species. The values of $g_{\mathrm{c}}$ for fitting a two-parameter function of radiation and vapour pressure deficit were obtained for a 3-d period by inverting the Penman-Monteith equation. Canopy conductance of pine was similar relative to spruce on ground area basis. This made $g_{\mathrm{c}}$ of pine larger relative to spruce per leaf area unit, since pine tree foliage mass was about one third that of spruce. Transpiration deficit was small in the growth season of 1995. It reached about $10 \%$ for spruce during the summer months. In 1994, however, the transpiration deficit was large for both species and extended throughout most of the growth season. During summer 1994, the decreased canopy conductance caused a 20 and $22 \%$ reduction in gross photosynthesis for pine and spruce, respectively, indicating a loss of production of at least that proportion. Pines were less sensitive to drought spells as compared to the more shallow-rooted spruces. On the other hand, spruce utilised the precipitation incoming in small quantities more effectively and responded faster. Species composition of boreal forest can affect stand scale fluxes and this should be recognised by process models. () Inra/Elsevier, Paris.)
\end{abstract}

transpiration deficit / sap flow / spruce / pine / drought

* Correspondence and reprints

Tel: (46) 18671168 ; fax: (46) 18 672795; e-mail: emil.cienciala@mv.slu.se 
Résumé - Flux d'eau dans une forêt boréale pendant deux années à pluviométrie contrastée ; régulation spécifique de la conductance du couvert et de la transpiration. La réduction de la transpiration sous l'effet de la sécheresse a été estimée dans une forêt boréale mélangée de 60 ans dans le centre de la Suède. La transpiration réelle a été estimée à partir des mesures directes de flux de sève chez Pinus sylvestris et Picea abies pendant deux années successives marquées par des précipitations contrastées. La réduction de transpiration (ou déficit de transpiration) liée à la sécheresse a été quantifiée par la différence entre le flux de sève mesuré et la transpiration calculée en conditions non limitantes de disponibilité en eau. La transpiration maximale a été estimée au pas de temps horaire à partir de l'équation de Penman-Monteith avec des paramètres de la fonction de conductance du couvert $\left(g_{\mathrm{c}}\right)$ calibrés pour chacune des deux espèces. Les valeurs de $g_{\mathrm{c}}$ pour ajuster une fonction à deux paramètres du rayonnement et du déficit de saturation de l'air ont été obtenues sur une période de $3 \mathrm{j}$ par inversion de l'équation de Penman-Monteith. La conductance du couvert ramenée à l'unité de surface au sol du pin était du même ordre de grandeur que celle de l'épicéa. Mais sachant que la biomasse foliaire des pins n'était environ que d'un tiers de celle des épicéas, $g_{c}$ était plus grande chez le pin par unité de surface foliaire. Le déficit de transpiration a été faible pendant la saison de végétation 1995, atteignant environ $10 \%$ chez l'épicéa pendant les mois d'été. En 1994, le déficit de transpiration a été important pour les deux espèces étudiées, et a duré une grande partie de la saison de végétation. Pendant l'été 1994, la réduction de la conductance du couvert a causé $20 \%$ de réduction de photosynthèse brute chez les pins, et $22 \%$ chez les épicéas, ce qui correspond à une perte de production sensiblement du même ordre. Les pins se sont montrés moins sensibles à la sécheresse que les épicéas, en liaison avec un système racinaire plus superficiel chez ces derniers. Toutefois, les épicéas ont montré une plus forte aptitude et une plus grande rapidité à utiliser les faibles précipitations. Ainsi, la composition en espèces de la forêt boréale peut influencer les flux à l'échelle du peuplement, ce qui doit être pris en compte dans les modèles. (@ Inra/Elsevier, Paris.)

déficit de transpiration / flux de sève/ sécheresse / Picea abies / Pinus sylvestris

\section{INTRODUCTION}

There is growing evidence of a higher frequency of climatic extremes on many places of the Earth $[17,36]$. Though the long-term precipitation mean may not be changing, the occurrence of extremely dry or wet years may affect the stability of forest ecosystems and cause a loss of production. Therefore, there is a need for long-term experiments, where ecophysiological performance of forest ecosystems is observed in situ for a range of soil water and climatic conditions with a detailed resolution. This is also extremely useful for providing sufficient material for validation of ecosystem models.

The higher frequency of climatic extremes can also impose a change in species composition when some species may accommodate to changing conditions better than others. In Sweden, the two major coniferous tree species Norway spruce (Picea abies (L.) Karst.) and Scots pine (Pinus sylvestris L.) constitute about $85 \%$ of the forested land, with respective shares of 47 and $38 \%$. These species are grown in mixed stands over a range of climatic and edaphic conditions, despite several obvious differences in their ecophysiology and architecture. Pine is a more light demanding species and forms low density crowns with a sparse foliage concentrated in the upper part of the stem. Spruce tolerates shade better than pine and does well as an understory species. Spruce forms dense canopies extending often to lower parts of the stem. The species also differ in root architecture: pine is a deeprooting species and it is thereby predisposed to perform better under dry spells relative to the shallow-rooted spruce. It is known that deep rooting helps to maintain a sufficient water supply under water 
deficit conditions (e.g. Kramer [21], Hinckley et al. [16] and Teskey and Hinckley [35]). However, a shallow root system may be advantageous when precipitation comes in small quantities. These differences raise questions on species-specific performance as regards water uptake, water economy and growth. Does pine really cope with drought better than spruce? How is the drought-induced reduction of canopy conductance manifested in the carbon budget? Are the species-specific differences in ecophysiology also important on a stand and regional level?

This paper addresses these questions by analysing the long-term continuous measurements of sap flow in a mixed subboreal forest in central Sweden. We combine the actual measurements with a simple modelling tool to quantify transpiration deficit for tree species. Our previous study from the site identified the uncertainty of transpiration deficit quantification when performed on a daily basis [9]. Therefore, we worked here with an hourly time step. Our measurements extended over 2 years with largely contrasting precipitation, illustrating the climatic variation typical for the area. We discuss species-specific ecophysiological performance based on the quantified actual and potential water use and also assess effects of drought-induced limitation to canopy conductance on photosynthesis.

\section{MATERIALS AND METHODS}

\subsection{Site description}

The detailed description of the NOPEX region can be found in Halldin et al. [15]. The central tower site $\left(60^{\circ} 5^{\prime} \mathrm{N}, 17^{\circ} 29^{\prime} \mathrm{E}\right.$, alt. $\left.45 \mathrm{~m}\right)$ is located in the Norunda Common about 30 $\mathrm{km}$ north of Uppsala. Forests in the area are mixtures of Norway spruce and Scots pine with the occasional occurrence of birch. They have been managed by forestry practices for over 200 years. Today, forests are a rich mosaic of stands that are distinguished by different spruce-pine quotients and age classes. The rotation period for stands in the area is typically 100 years. The soil is a deep boulder-rich sandy till of glacial origin. At the site, the soil was podzolized and classified as Dystric Regosols [34].

\subsection{Meteorological variables}

A continuous climatic data set for both 1994 and 1995 at the Norunda (NOPEX central) site, where the sap flow measurements were made, was not available. The data from the central NOPEX site available for this study (SINOP database) included solar radiation and air temperature for a part of the period evaluated here. We have therefore used air temperature and relative humidity data from a climatic station in Siggefora, about $15 \mathrm{~km}$ away. That station was collecting data above a forest of similar age and structure and the comparison of available temperature and radiation records showed that the discrepancies were mostly below $3 \%$ and therefore neglected. Net radiation was calculated as a simple linear function of short-wave radiation with intercept and slope parameters of 23.8 and $0.77 \mathrm{~W} \mathrm{~m}^{-2}$, respectively, as found over a stand of similar age and species composition in Siggefora. Daily precipitation data were collected at the site for most of the season; the missing periods were filled with an average of the gauge measurements from three neighbouring sites in the region.

\subsection{Stand description, sap flow and transpiration}

The studied stand was 50 years old, with the basal area of $29.3 \mathrm{~m}^{2} \mathrm{ha}^{-1}$ and a maximum stand height of $23 \mathrm{~m}$. The canopy was closed with occasional openings. The projected leafarea index (LAI) was about 4-5. The stand was composed of Norway spruce (Picea abies (L.); $66 \%$ of the stand basal area) and Scots pine (Pinus sylvestris (L.); $33 \%$ ) with a few specimens of birch (Betula alba (L.)).

Sap flow rate was measured on 12 trees with two measuring points on each. We used the standard equipment from Environmental Measuring Systems (P690.2), which is based on the technique described by Cermak et al. [6] and Kucera et al. [22]. Two instruments 
provided 24 measuring channels equally distributed between pine and spruce trees. Measurements were performed throughout two growth seasons. For the second growth season, a new set of sample trees was selected. The tree selection in 1994 was aimed at covering the frequency distribution of stem diameters in the stand for individual species. In 1995, the selection of trees was similar, but a weight was given to the upper diameter classes with trees whose contribution to total stand transpiration was more important. The breast height diameter over bark of the measured trees ranged from 17 to $36 \mathrm{~cm}$.

Stand transpiration was estimated from the measured tree sap flow using the ratio of a foliage biomass supported by the set of the measured trees and that of the stand. This was performed individually for pine and spruce; foliage mass was calculated using the Swedish biomass functions of Marklund [26]. The use of the foliage mass was required to weight the differences in mean tree diameters when selecting tree samples in the two measurement years. The procedure accounts for the non-linearity of the relationship between stem diameter and supporting foliage mass, which is important when the mean stem diameter of the sample tree set differs from the corresponding mean of all trees in a stand.

To enable species-specific analyses, we expressed water uptake of pine and spruce trees separately to represent a flux of hypothetical monospecific stands of either pine or spruce. These stands had an equal basal area (that of the actual mixed stand), but a different LAI due to a different foliage mass of pine and spruce canopies (see below). Most of the analyses were performed on diurnal courses (time step of $15 \mathrm{~min}$ ) for respective tree species. Since scaling the tree sap flow rates to stand transpiration is conveniently performed on a daily basis, the diurnal courses ( $15 \mathrm{~min}$ or hourly resolution) of sap flow representative for monospecific pine and spruce stands in absolute units $(\mathrm{mm} / \mathrm{h})$ were obtained as follows: the respective daily totals were interpolated to the average diurnal courses of sap flow from all measuring points for the respective species. This way, the diurnal dynamics of sap flow for species was retained, representing an average for a stand and the fluxes were expressed in correct absolute units.

Some missing values in the sap-flow measurements on daily basis were interpolated using the regression between daily sap flow of species and potential evaporation according to Turc [37] at the start and end of the missing periods. These values are identified by a symbol if applicable.

\subsection{Parameterization of canopy conductance}

Canopy conductance $\left(g_{\mathrm{c}}\right)$ was calculated and parameterized for hypothetical monospecific stands of either pine or spruce on an hourly basis. The period of three sunny days in July (9-11th) was selected for these calculations. The selection was made to avoid limitations to transpiration flux by soil water deficit and soil hydraulic limitations and/or very high evaporative conditions with a potential partial embolism of conductive tissues. The speciesspecific sap flow was cross-correlated with the product of short-wave radiation and vapour pressure deficit to estimate an average time delay of the sap flow course behind the likely course of transpiration. For this, only relative values are considered and the magnitude of variables are not of any importance in this phase. The mean time lag valid for the 3-d parameterization period was 15 and $30 \mathrm{~min}$ for pine and spruce, respectively. With this time lag, the correlation between sap flow and the product of VPD and radiation was tight and reached $r=0.92$ and $r=0.91$ for pine and spruce, respectively. Sap flow was thereby accordingly shifted in time to mimic the rate of transpiration. Other effects of plant capacitance apart from the time shift were neglected in the analyses.

Canopy conductance was then calculated from the inverse of the Penman-Monteith equation with known transpiration fluxes estimated form the measured sap flow that was corrected for its time lag behind transpiration. The storage term was assumed negligible and aerodynamic conductance $\left(g_{\mathrm{a}}\right)$ was calculated from a wind profile equation valid for near stable conditions. The fraction of the net radiation that is absorbed by the canopy $\left(R_{\mathrm{n}}\right)$ was estimated from net radiation above canopy $\left(R_{\mathrm{no}}\right)$ according to the Beer's law:

$$
R_{\mathrm{n}}=R_{\mathrm{no}} *[1-\exp (-k * \mathrm{LAI})]
$$

where $k$ is the extinction coefficient (set to 0.5 here) and LAI is the projected leaf area index 
$(-)$. LAI for the hypothetical pine or spruce monospecific stands was calculated from the total stand LAI (4.6) and the proportion of the current foliage mass of the species. The foliage mass was calculated using the biomass functions of Marklund [26]. The species foliage mass represented 14 and $86 \%$ of the total actual stand foliage mass for pine and spruce, respectively. Using the current basal area for stand and species, and the amount of leaf biomass, it was estimated that a monoculture of pine with the basal area of the present stand $\left(29.3 \mathrm{~m}^{2}\right)$ would have LAI of 2.0 , whereas a pure spruce stand would reach LAI of 5.8. These LAI values are similar as published elsewhere for actual monospecific stands of pine (e.g. Lindroth [23]) and of spruce [1] in Sweden. The schematic distribution of tree foliage mass and the measured and approximated green crown height for the individual species is shown in figure 1 .

The equation applied for parameterization of $g_{\mathrm{c}}$ was a simplified form of Lohammar [24] equation. In that equation, we linearized the radiation term giving the final form of

$$
g_{\mathrm{c}}=\mathrm{p}_{1} * R_{\mathrm{g}} /\left(1+\mathrm{p}_{2} * \mathrm{VPD}\right)
$$

where $\mathrm{p}_{1}, \mathrm{p}_{2}$ are parameters to be fitted, $R_{\mathrm{g}}$ is the short-wave radiation $\left(\mathrm{W} \mathrm{m}^{-2}\right)$ and $\mathrm{VPD}$ is vapour pressure deficit $(\mathrm{kPa})$. The fitting was performed with the weight given by the actual value of $g_{c}$. This minimizes the influence of night values, when $g_{\mathrm{c}}$ approaches zero and variations in $g_{\mathrm{c}}$ have practically no importance for calculation of transpiration fluxes. For weighted least square fitting, weights are included in the sum of squares to be minimized. To avoid adding a sub-function of air temperature $\left(T_{\mathrm{a}}\right)$ into equation (2), $g_{c}$ was set to zero for the days with average daily $T_{\mathrm{a}}$ less than $5^{\circ} \mathrm{C}$. The criteria for the goodness of fit were standard error of the estimate and coefficient of determination $\left(r^{2}\right)$.

\subsection{Effect of soil drought on water and carbon fluxes - quantification}

The effect of drought on transpiration was quantified as a difference between potential and actual fluxes, which is herewith called transpiration deficit. The fluxes were represented by the calculated drought-free transpiration $(E)$ and the transpiration estimated from sap flow measurements $\left(E_{\mathrm{Q}}\right)$; these analyses were per-

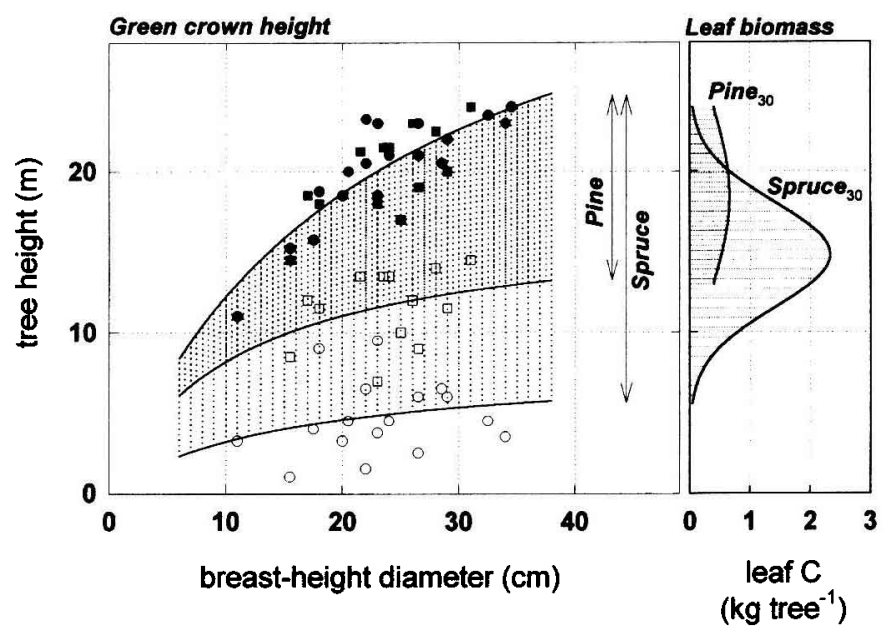

Figure 1. Left: green crown height of trees in the stand: crown bottom (open symbols) and top (filled symbols) for sample pine (squares) and spruce (circles) trees, approximated by hyperbolic curves. Right: foliage mass of a pine and spruce tree with a diameter at breast height of $30 \mathrm{~cm}$ distributed along the tree axis by a gaussian function. 
formed separately for pine and spruce, which were normalized into corresponding monospecific stands as outlined above.

The effect of a decreased canopy conductance on production was assessed for a period of three summer months (1 July to 30 September) using the photosynthesis module of FOREST-BGC $[30,31]$. In the model, the equation from Lohammar et al. [24] combines mesophyll and stomatal conductance to calculate gross photosynthesis. Mesophyll conductance, which represents the leaf biochemistry processes, was calculated for the actual mixed stand using FOREST-BGC with parameterization from Cienciala et al. [10] and it was assumed to be equal for the hypothetical monocultures of individual tree species. Stomatal/canopy conductance to $\mathrm{CO}_{2}$ was obtained from $g_{\mathrm{c}}$ to water vapour as described above, which was corrected by the factor 1.56 to account for differences in diffusivity between water vapour and $\mathrm{CO}_{2}$.

\section{RESULTS}

\subsection{Climatic conditions}

The annual precipitation decreased in the 1990s (91-95) as compared to the 1980s. The difference between the average annual precipitation was about $160 \mathrm{~mm}$ and the 1990 s were evidently drier. The annual precipitation in the region varied from about 450 to $970 \mathrm{~mm}$ between dry and wet years in the period 1981-1995. There was also a large variability in the distribution of precipitation within a year. For the two studied measurement years of 1994 and 1995, there was a difference in cumulative precipitation - over $170 \mathrm{~mm}$ during a large part of the growth season (figure 2), though the annual sums differed only by about $100 \mathrm{~mm}$.

Apart from precipitation, the climatic conditions were similar for the two studied years, 1994 and 1995. The mean daily evapotranspiration for the growth seasons of 1994 and 1995 calculated according to the Turc [37] equation reached 2.53 and $2.23 \mathrm{~mm}$, and the seasonal sum of 450 and $424 \mathrm{~mm}$, respectively. The length of the growth season was 178 and 190 days for 1994 and 1995, respectively, using the threshold of $5{ }^{\circ} \mathrm{C}$ for daily mean air temperature.

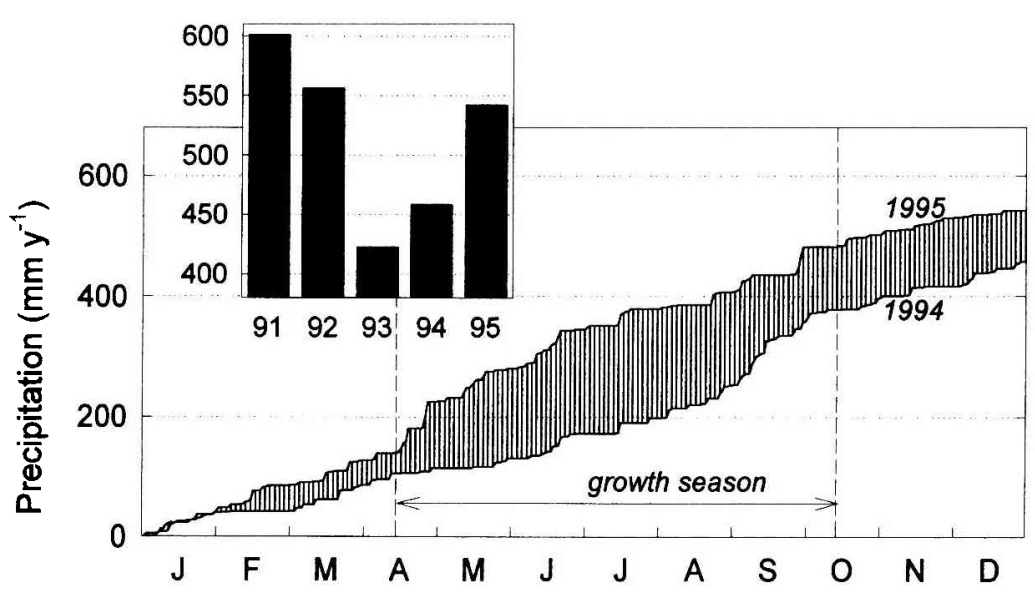

Figure 2. Annual precipitation during the period 1991-1995 (bars) and cumulative precipitation for the two measurement years of 1994 and 1995 . 


\subsection{Parameterized canopy conductance and drought-free transpiration}

For the 3 days (9-11 July 1995) selected for parameterization of canopy conductance $\left(g_{\mathrm{c}}\right)$ function, the fitted function explained 88 and $80 \%$ of the variation in actual hourly data of $g_{\mathrm{c}}$ for pine and spruce, respectively, with standard error of the estimate $0.0001 \mathrm{~m} \cdot \mathrm{s}^{-1}$ in both cases (figure 3). The fitted parameters (coefficient of variation) $p_{1}$ and $p_{2}$ were $2.06 \mathrm{E}$ $5 \mathrm{~m} \cdot \mathrm{s}^{-1}(15.3 \%)$ and $0.68 \mathrm{kPa}(35.5 \%)$ for pine, and $1.60 \mathrm{E}-5 \mathrm{~m} \cdot \mathrm{s}^{-1}(16.4 \%)$ and $0.21 \mathrm{kPa}(82.5 \%)$ for spruce, respectively. The fitted $g_{c}$ functions for species had similar magnitudes on canopy level. However, canopy conductance expressed per unit leaf area would be higher for pine as compared to spruce approximately in the ratio of 2 to 1 .

The calculated drought-free (i.e. potential) transpiration, that was calculated using the parameterized $g_{\mathrm{c}}$ functions, explained 94 and $91 \%$ of the variations of the time-shifted sap-flow rate for the

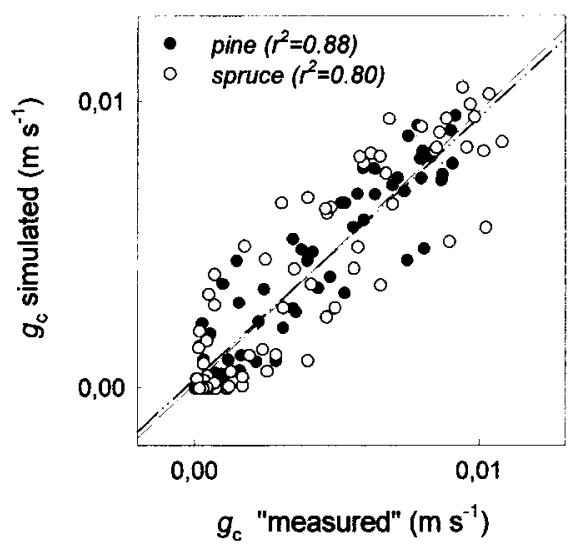

Figure 3. Parameterization of the canopy conductance functions [equation (2)]: the 'actual' against the fitted hourly conductance values for 9-11 July 1995 and the regression lines for pine (-.-) and spruce (-..-). 3-d parameterization period for pine and spruce, respectively. For the actual mixed stand, the simulated drought-free transpiration $(E)$ was similar for the two growth seasons of 1994 and 1995: the daily mean values reached 1.34 and $1.17 \mathrm{~mm}$ and the seasonal sum was 238 and $223 \mathrm{~mm}$, respectively. $E$ for a hypothetical pine stand was similar to a spruce stand when fluxes were low. On the other hand, $E$ of spruce is up to about $25 \%$ larger for summer months, when evaporative conditions were high (figure 4). For 1994, the seasonal daily average (seasonal total) of potential $E$ reached $1.21(215)$ and 1.42 (253) $\mathrm{mm}$ for pine and spruce monospecific stands, respectively. For 1995, which was more moist, the corresponding values of $E$ were slightly lower and reached 1.07 (203) and $1.24(235) \mathrm{mm}$ for pine

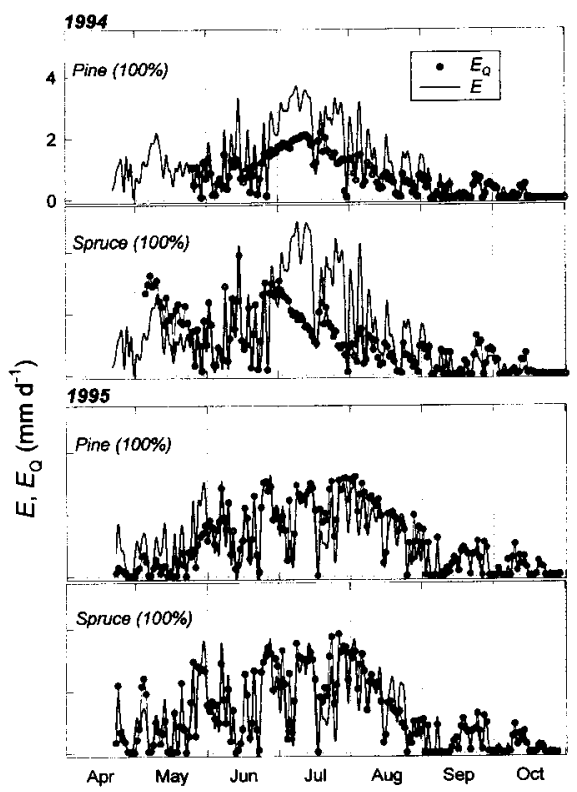

Figure 4. Daily values of actual measured transpiration (sap flow, $E_{\mathrm{Q}}$, extrapolated values noted by grey fills in symbols) and simulated drought-free transpiration $(E)$ for hypothetical pine and spruce monospecific stands in 1994 and 1995. 
and spruce monospecific stands, respectively.

\subsection{Transpiration deficit}

The actual transpiration $\left(E_{\mathrm{Q}}\right)$ was lower than the drought-free transpiration $(E)$ for most of the growth season in 1994 , whereas these two fluxes matched each other for most of the following growth season in 1995 (figure 4). The reduction in transpiration (transpiration deficit) was largest in July 1994 for both species. In 1994, transpiration deficit was small or non-existing during the second half of September and October for both pine and spruce, and also during June for spruce. In 1995 , the fluxes of $E$ and $E_{\mathrm{Q}}$ reached similar magnitudes for both species even during high evaporative conditions in the summer months, showing low or non-existent limitations to transpiration by drought. However, a small transpiration deficit developed for spruce, e.g. in August and June. For pine, there was no detectable reduction in transpiration by drought for most of the growth period. However, the fluxes of $E_{\mathrm{Q}}$ were considerably lower as compared to $E$ during spring. This was obvious mostly in 1995 when more measured data were available to build a continuous record for the spring period (figures 4 and 5). For both species, there was a 10-d period at the end of July 1995 , when $E$ was lower than $E_{\mathrm{Q}}$. In this period, the temperature was unusually low and

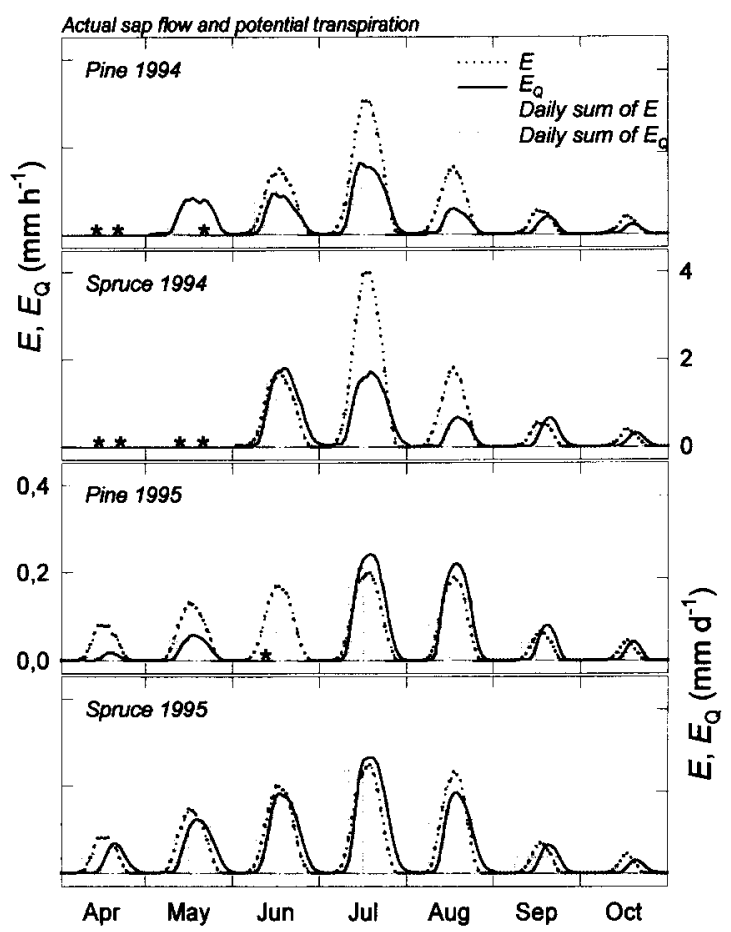

Figure 5. Average monthly daytime courses (lines, left scale) and daily sums (bars, right scale) of sap flow $\left(E_{\mathrm{Q}}\right)$ and drought-free transpiration $(E)$ for spruce and pine. Missing values are noted by a star. 
radiation was highly variable due to passing scattered clouds.

The differences in water supply for the two growth seasons changed both the magnitude of the measured fluxes and the shape of the diurnal sap flow curve (figure 5). The example period of two similar days in July documents the large differences in measured sap flow between the two years of 1994 and 1995 (figure 6).
The diurnal courses of $E_{\mathrm{Q}}$ and $E$ were similar in shape and magnitude for the periods of sufficient water supply. The time lag between $E_{\mathrm{Q}}$ and $E$ was small - about 0-30 min - during summer period and sufficient water supply: under these conditions the rates of $E$ and $E_{\mathrm{Q}}$ practically matched (figures 6 and 7). A diurnal sap flow curve under deficit conditions was typically less correlated to the predicted

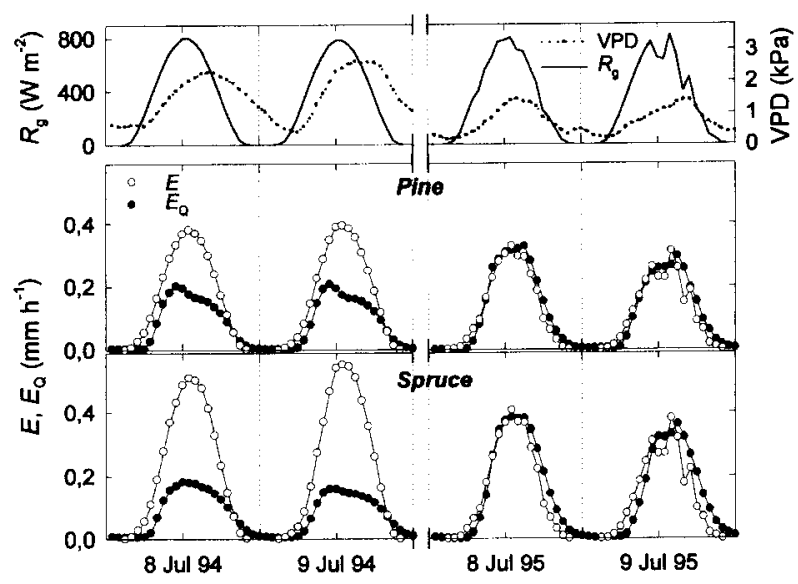

Figure 6. Diurnal curves of actual sap flow $\left(E_{\mathrm{Q}}\right)$ and drought-free transpiration $(E)$ for pine and spruce: the identical period of two summer days 8-9 July in the dry year of 1994 and in the moist year of 1995. Top: short-wave radiation $\left(R_{\mathrm{g}}\right)$ and vapour pressure deficit (VPD).

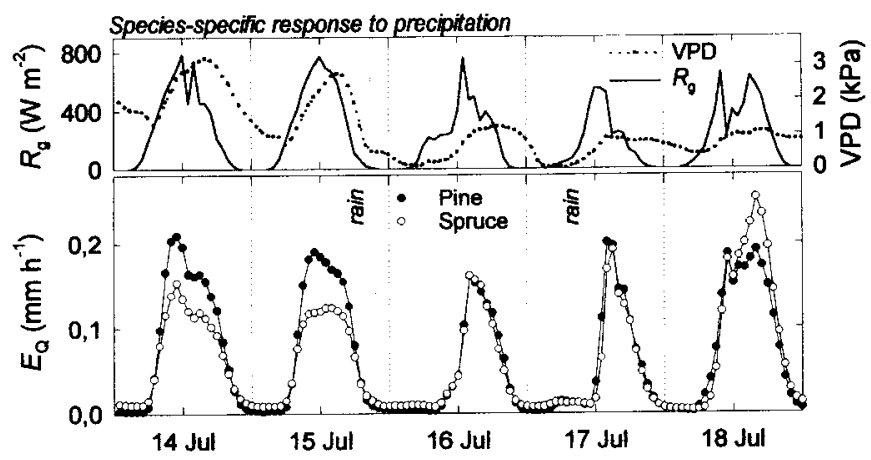

Figure 7. Sap flow $\left(E_{\mathrm{Q}}\right)$ : species-specific responses to precipitation after a dry period. Top: short-wave radiation $\left(R_{\mathrm{g}}\right)$ and vapour pressure deficit (VPD). 
rate of $E$ and the time lag between $E_{\mathrm{Q}}$ and $E$ increased. The time lag also increased during the autumn, when air temperature decreased.

The progression of transpiration deficit during the pronounced dry spell 1-15 July 1994 was different for different species (figure 4). Pine was able to balance a part of the evaporative demand: the fluxes of $E$ and $E_{\mathrm{Q}}$ correlated reasonably well and $E_{\mathrm{Q}}$ was reaching about $60 \%$ of $E$ during that period. On the contrary, transpiration in spruce gradually declined and $E_{\mathrm{Q}}$ reached only about a third of $E$ at the end of this dry spell. However, the recovery after rain was usually more rapid for spruce trees as compared to pines. An example of this can be seen on the period of 14 to 18 July 1994 (Figures 4 and 7). Here, 14 and 15 July are the last days of the previous warm and dry period that resulted in considerable transpiration deficit - about $40 \%$ in pine and $70 \%$ in spruce. Both species reacted strongly to precipitation events on 15 and 17 July and largely increased their water uptake relative to evaporative conditions. This increase was stronger in spruce trees: after the rains, $E_{\mathrm{Q}}$ reached higher magnitudes than during the previous warm period, despite the much lower vapour pressure deficit at that time.

\subsection{Limitations to carbon assimilation}

A comparison of the drought-induced limitations to water and carbon cycle for the summer period showed large differences between the dry year, 1994, and the more moist year, 1995. In 1994, the drought-reduced canopy conductance for the 3-month period July-September reduced transpiration by 41 and $46 \%$ in pine and spruce, respectively. The assessment by the carbon module of the FOREST-BGC model showed that this affected the tree carbon cycle by limiting gross photosynthesis by 20 and $22 \%$, respectively (figure 8). In 1995, the effect of drought for the period July-September was small and beyond the accuracy of the applied estimation for pine trees. A temporary reduction in fluxes occurred in

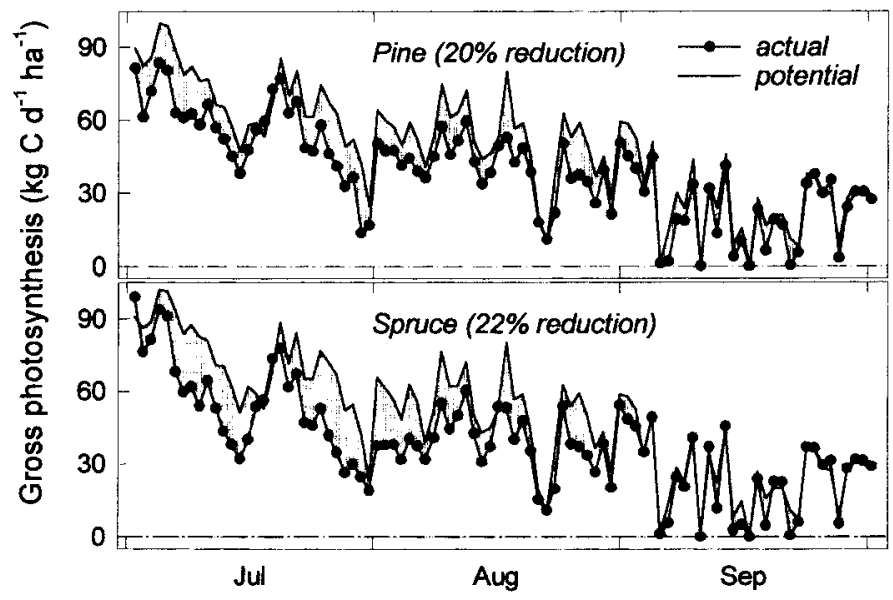

Figure 8. Drought limitation of gross photosynthesis for pine and spruce stands for the 3 months of 1994: actual (symbols) and potential photosynthesis and the difference noted by shading. 
August for spruce (figure 5), but these quantities were small relative to seasonal water or carbon budget.

\section{DISCUSSION}

\subsection{Methodical aspects of transpiration deficit analysis}

The parameterized $g_{c}$ and the PenmanMonteith equation is a robust, but sensitive detection tool for quantification of transpiration deficit. The previous work from the site suggested that analysis of transpiration deficit performed with a daily time step was uncertain and a finer resolution was recommended [9]. The hourly resolution permits us to utilize the information given by the shape of the diurnal sap flow curve as a sensitive indicator of drought conditions on a tree/stand level. The resolution also permits parameterization to be performed over a much shorter time period. Selecting another period of the moist year 1995 for parameterization indicated differences in transpiration calculations of about $10 \%$. This is an acceptable accuracy with respect to the minimum parameterization involved.

The problem associated with hourly/ minute analyses is the asymmetrical shape of the sap flow curve with respect to transpiration. These two fluxes usually correlate well under high flow conditions in the middle of the day, whereas similarity decreases at the onset and the end of the day, when the effect of tree capacitance increases and the accuracy of the sap flow measurements decreases. The capacitance effects in trees have been described elsewhere (e.g. Schulze et al. [33], Carlson and Lynn [5], Machado and Tyree [25] and Köstner et al. [19]). A rigorous treatment of time lag requires a model that includes plant capacitance and resistance, such as, e.g. SPAC [20]. For practical pur- poses, however, most authors use a constant value of time lag between transpiration and sap flow; they use it not only for a diurnal course of a particular day, but also across a season. For example, Granier and Loustau [13] used a constant time lag of $1 \mathrm{~h}$ for different sites and years and noted that this could be the reason for some of the differences between their modelled and observed transpiration rates. Köstner et al. [18] noted that a correction for a sap flow time lag of increased maximum $g_{c}$ values calculated via sap flux by a factor of ca 1.6. Our data indicate that the time lag increased both under water deficit conditions and towards the end of the season (figure 5), probably correlated with a decreasing air temperature. Apparently, there is a need to adapt some of the capacitance models to assist with the analyses of $g_{c}$ providing a more realistic estimate of time lag and transpiration using sap flow data. The problem discussed above is associated mostly with low-speed conducting systems such as that of conifers. It is also obvious that the capacitance effects increase with tree size and with decreasing flux rate and water tension inside trees. The correlation of sap flow and transpiration rates can be very high for more rapidly transpiring and/or smaller trees, where the problems of heat balance technique discussed above diminish [8]. The above estimation of the time lag using the product of radiation and vapour pressure deficit that is cross-correlated with the sap flow curve may be a good approximate solution when actual transpiration is not available.

Another problematic area in parameterization of conductance data is the treatment of night values. These are sometimes included (e.g. Gärdenäs and Jansson, [12]) and sometimes omitted [4] in calculations of mean daily $g_{c}$ and for fitting analyses. To emphasise the importance of high daylight conductance values relative to low $g_{c}$ during nights, we fitted the conductance 
function equation (2) with larger weight for large $g_{c}$. This decreased the standard error of the estimations in equation (2) for both species.

The conductance function with linearized radiation member has the advantage of minimum parameters for fitting. It is obvious, that a fully exposed leaf would require a curvilinear radiation response function to modulate saturation. However, this is not required for dense coniferous canopies of northern latitudes, where canopy light saturation effect is unlikely.

\subsection{Transpiration deficit for pine and spruce}

The data demonstrate that trees respond sensitively to fluctuations of moisture. Transpiration is limited by both annual variation in precipitation and its seasonal distribution. The results for the summer period of 1994 show that the quantitative differences in transpiration deficit between pine and spruce were small in the studied mixed stand. However, it would be too early to conclude that species composition has little importance for modelling purposes on a regional scale. In the studied mixed stand, trees were most probably fully adapted to coexistence. A pure monospecific stand may develop a different strategy of water use and this should be verified by independent measurements.

We could not explain the decreased water uptake for pine during the spring period (figure 4). In spring of 1995, water was abundant at the site and also spruce transpiration matched the predicted rates of $E$ at that time. A similar transpiration pattern for species was also observed in the following spring periods of 1996 and 1997 (data not shown). The measurements of soil temperature in different depths showed a small or non-existent temperature gradient during the spring period (Erik
Kellner, unpublished data). At that time, soil temperature near the surface becomes higher relative to that in deeper layers, whereas the opposite gradient is observed for winter period. Therefore, we rejected the hypothesis of soil temperature gradient and low temperatures in the deeper layers as the reason for decreased pine transpiration. We speculate that the low pine transpiration rates in spring are associated with species-specific fine-root growth.

For moist conditions, simulated transpiration and the measured fluxes mostly matched with differences of about $10 \%$, which is an expected accuracy with respect to the used tree sample density [7]. For the second half of July 1995 the rates of measured $E_{\mathrm{Q}}$ temporarily exceeded the rates of modelled $E$, which is also pronounced on the average monthly values (figure 5). At that time, temperature was unusually low and radiation was very scattered by high clouds. We tested the parameterized FOREST-BGC model that uses the Penman-Monteith equation on a daily basis and that was previously parameterized for the site on a stand level [10]. The model showed similarly low fluxes of transpiration that were also exceeded by the actual measurements of water uptake for that period. We suspect that the specific combination of diffuse radiation and other climatic variables made the Penman-Monteith-based calculations to under-predict the actual transpiration rates at that time.

The analyses above, however, do not explain the action of the regulatory mechanisms available to trees. For example, too little is known about fine-root growth of the full-grown and old trees. For smaller trees, Santantonio [32] noted that this process may be very dynamic and compensates for uptake in drought spells within a season. Some experiments indicate a decreased allocation of carbon to roots under drought $[3,13]$, reduced surface root growth [2] and reallocation of root growth to deeper layers [29], whereas other stud- 
ies show an increased root growth under drought [11]. Our data show a good correspondence of $E$ and $E_{\mathrm{Q}}$ for several moist periods across the two measurement years (figure 5). This is indirect evidence that root growth dynamics was not large enough to alter the parameterized rates of transpiration during the studied period.

Another uncertainty is the VPD response in the conductance model. This or a similar negative response is frequently used in conductance models, though it very likely only reflects the limitations that are caused by other factors (water tensions in plant and soil and total resistance of plant to flow). Therefore, the estimated rates of potential transpiration during very high evaporative conditions (e.g. July 1994) remain uncertain and should be validated, e.g. by an irrigation experiment in the field.

\subsection{Drought limitations to photosynthesis}

Carbon and water cycles in a tree are tightly linked by sharing stomata as a common pathway for water and carbon fluxes. This way, a drought-induced decrease of stomatal conductance limits both transpiration and the rate of carbon assimilation. Since carbon assimilation involves additional resistances in the mesophyll cells, the relationship between water and carbon fluxes is not linear. Our assessment of the drought effects on carbon assimilation was only approximate. Nevertheless, the estimated decrease in gross photosynthesis of about $20 \%$ for the summer period of 1994 indicates that the magnitude of production loss in the region is considerable. In the complete tree carbon budget, respiration fluxes are rather conservative as they are mostly related to the amount of standing biomass. This suggests that the relative losses of merchantable production will still be higher than the above estimated decrease in photosynthesis. There is not much literature on the magnitude of the effect of drought on production for adult trees and stands, because most of the studies were performed on seedlings or young trees. Swedish studies performed on a ca 25 year-old Norway spruce indicated an above-ground accumulation of carbon in irrigated trees of about $30-40 \%$ relative to the drought-treated ones $[27,28]$.

Drought limitation to photosynthesis was quantitatively similar for the species during the summer period of 1994. The observed differences were not significant with respect to the simplifications involved in the tree carbon balance assessment (assumed equal photosynthetic capacity for the two species). However, similarly as for transpiration, larger differences between species may be expected if real monospecific stands were compared, where trees may establish a site-specific water balance. For the mixed stands in the region, a competition for water will probably be less important as compared to the light requirements, which are of major importance for pine trees.

\section{CONCLUSIONS}

Pine and spruce have specific responses to drought and this may affect water and carbon fluxes on larger spatial scales. However, for the studied summer period, the effects of drought were quantitatively similar for the two species.

Parameterized canopy conductance and the Penman-Monteith equation are easy tools for analysis of the measured fluxes and quantification of transpiration deficit - especially with respect to the minimal amount of used parameters. An hourly time step largely reduces the length of the period required for parameterization of conductance functions; it increases the sensitivity of transpiration deficit analy- 
sis by using the shape of diurnal flux curves to identify water deficit conditions. However, it is important to understand that the approach offers practically no explanation of the mechanisms that make trees limit their water uptake. Such a task would require a physically sound nonsteady state simulation of water tensions in soil and trees with a fine time resolution. This will be the topic of our next study.

\section{ACKNOWLEDGEMENTS}

We thank Jan Seibert for precipitation data and Erik Kellner for access to soil temperature measurements. We are indebted to Ann-Sofie Morén for assistance with sap flow instrumentation and data retrieval. Some of the climatic variables were retrieved from SINOP database of the NOPEX project. Funding for this project was obtained from the Swedish Natural Science Research Council (NFR) and from the Swedish Council for Forestry and Agricultural Research. The senior author also acknowledges the support from NFR in his postdoctoral stay at the Rocky Mountain Experiment Station, USDA, Fort Collins, Colorado, USA.

\section{REFERENCES}

[1] Alavi G., Radial stem growth of Picea abies in relation to spatial variation in soil moisture conditions, Scand. J. For. Res. 11 (1996) 209-219.

[2] Beier C., Gundersen P., Hansen K., Rasmussen L., Experimental manipulation of water and nutrient input to a Norway spruce plantation at Klosterhede, Denmark. II. Effects on tree growth and nutrition, Plant Soil 168-169 (1995) 613-622.

[3] Blanck K., Lamersdorf N., Dohrenbusch A., Murach D., Response of a Norway spruce forest ecosystem to drought/rewetting experiments at Solling, Germany, Water Air Soil Pollut. 85 (1995) 1251-1256.

[4] Bringfelt B., Lindroth A., Synoptic evapotranspiration model applied to two northern forests of different density, J. Hydrol. 95 (1987) 185-201.

[5] Carlson T.N., Lynn B., The effects of plant water storage on transpiration and radiomet- ric surface temperature, Agric. For. Meteorol. 57 (1991) 171-186.

[6] Cermak J., Deml M., Penka M., A new method of sap flow rate determination in trees, Biol. Plant (Praha) 15 (3) (1973) 171-178.

[7] Cermak J., Cienciala E., Kucera J., Lindroth A., Bednarova E., Individual variation of the sap-flow rate in large pine and spruce trees and stand transpiration: A pilot study at the central NOPEX site, J. Hydrol. 168 (1995) 17-28.

[8] Cienciala E., Lindroth A., Gas-exchange and sap flow measurements of Salix viminalis trees in short-rotation forest. I. Transpiration and sap flow, Trees Struct. Funct. 9 (5) (1995) 289-294.

[9] Cienciala E., Kucera J., Lindroth A., Cermak J., Grelle A., Halldin S., Canopy transpiration from a boreal forest during a dry year, Agric. For. Meteorol. 86 (1997) 157-167.

[10] Cienciala E., Running S.W., Lindroth A., Grelle A., Ryan M.G., Analysis of carbon and water fluxes from the NOPEX boreal forest: Comparison of measurements with FOREST-BGC simulations, J. Hydrol. (1998) in press.

[11] Clemensson L.A., Asp H., Fine-root morphology and uptake of $32 \mathrm{P}$ and $35 \mathrm{~S}$ in a Norway spruce (Picea abies (L.) Karst.) stand subjected to various nutrient and water supplies, Plant Soil 173 (1995) 147-155.

[12] Gärdenäs A.I., Jansson P.E., Simulated water balance of scots pine stands in Sweden for different climate change scenarios, J. Hydrol. 166 (1995) 107-125.

[13] Gerant D., Podor M., Grieu P., Afif D., Cornu S., Morabito D., Banvoy J., Robin C., Dizengremel $\mathrm{P}$., Carbon metabolism enzyme activities and carbon partitioning in Pinus halepensis Mill. exposed to mild drought and ozone, J. Plant Physiol. 148 (1996) 142-147.

[14] Granier A., Loustau D., Measuring and modelling the transpiration of a maritime pine canopy from sap-flow data, Agric. For. Meteorol. 71 (1994) 61-81.

[15] Halldin S., Gottschalk L., van de Griend A.A., Gryning S.-E., Heikinheimo M., Högström U., Jochum A., Lundin L.-C., Science plan for NOPEX, Technical Report No. 12, Uppsala University, Uppsala, 1995.

[16] Hinckley T.M., Dougherty P.M., Lassoie J.P., Roberts J.E., Teskey R.O., A severe drought: impact on tree Quercus alba growth, phenology, net photosynthetic rate and water relations, Am. Midl. Nat. 102 (2) (1979) 307-316.

[17] Karl T.R., Knight R.W., Plummer N., Trends in high frequency climate variability in the 
twentieth century, Nature 377 (1995) 217-220.

[18] Köstner B., Biron P., Siegwolf R., Granier A., Estimates of water vapor flux and canopy conductance of Scots pine at the tree level utilizing different xylem sap flow methods, Theoret. Appl. Climat. 53 (1996) 105-113.

[19] Köstner B., Alsheimer M., Falge E., Geyer R., Tenhunen J.D., Relationship between canopy transpiration, conductance, and tree capacitance of an old Norway spruce (Picea abies) stand, Ann. Sci. For. 54 (1997) 125-139.

[20] Kowalik P.J., Turner N.C., Diurnal changes in the water relations and transpiration of a soybean crop simulated during the development of water deficits, Irrig. Sci. 4 (1983) 225-238.

[21] Kramer P.J., Water Relations of Plants, Academic Press, Inc, New York, 1983.

[22] Kucera J., Cermak J., Penka M., Improved thermal method of continual recording the transpiration flow rate dynamics, Biol. Plant (Praha) 19 (6) (1977) 413-420.

[23] Lindroth A., Canopy conductance of coniferous forests related to climate, Water Resources Res. 21 (3) (1985) 297-304

[24] Lohammar T., Larsson S., Linder S., Falk S., FAST - simulation models of gaseous exchange in Scots pine, in: T. Persson (Ed.), Structure and Function of Northern Coniferous Forests - An Ecosystem Study, Ecol. Bull. 32 (1980) 505-523.

[25] Machado J.L., Tyree M.T., Patterns of hydraulic architecture and water relations of 2 tropical canopy trees with contrasting leaf phenologies - Ochroma pyramidale and Pseudobombax septenatum, Tree Physiol. 14 (1994) 219-240.

[26] Marklund L.G., Biomass functions for pine, spruce and birch in Sweden, Dept Forest Survey, Swedish University of Agricultural Sciences, Umeå, Rep 45, 1988, pp. 1-73.

[27] Nilsson L.O., Carbon sequestration in Norway spruce in South Sweden as influenced by air pollution, water availability, and fertilisation, Water Air Soil Pollut. 70 (1993) $177-186$
[28] Nilsson L.-O., Wiklund K., Influence of nutri ent and water stress on Norway spruce production in south Sweden: The role of air pollutants, Plant Soil 147 (1992) 251-265.

[29] Persson H., Von Fircks Y., Majdi H., Nilsson L.-O., Root distribution in a Norway spruce (Picea abies (L.) Karst.) stand subjected to drought and ammonium-sulphate application, Plant Soil 168-169 (1995) 161-165.

[30] Running S.W., Coughlan J.C., FOREST$\mathrm{BGC}, \mathrm{A}$ general model of forest ecosystem processes for regional application. I. Hydrologic balance, canopy gas exchange and primary production processes, Ecol. Modelling 42 (1988) 125-154.

[3I] Running S.W., Gower S.T., FOREST-BGC, A general model of forest ecosystem processes for regional application. II. Dynamic carbon allocation and nitrogen budgets, Tree Phys. 9 (1991) 147-160.

[32] Santantonio D., Hermann R.K., Overton W.S., Root biomass studies in forest ecosystems, Pedobiologia 17 (1977) 1-31

[33] Schulze E.-D., Cermak J., Matyssek R., Penka M., Zimmerman R., Vasicek F., Gries W., Kucera J., Canopy transpiration and water fluxes in the xylem of the trunk of Larix and Picea trees - a comparison of xylem flow, porometer and cuvette measurements, Oecologia (Berlin) 66 (1985) 475-483.

[34] Stähli M., Hessel K., Eriksson J., Lindahl A. Physical and chemical description of the soil at the NOPEX central tower site, NOPEX Technical Report No. 16, Dept Soil Sci., Swedish Univ. Agric. Sci., Uppsala, Sweden, 1995.

[35] Teskey R.O., Hinckley T.M., Influence of temperature and water potential on root growth of white oak, Physiol. Plant 52 (1981) 363-369.

[36] Tsonis A.A., Widespread increases in lowfrequency variability of precipitation over the past century, Nature, 6593 (382) (1996) 700-702.

[37] Turc L., Évaluation des besoins en eau d'irrigation évapotranspiration potentielle, Ann .Agronom. 12 (1961) 13-49. 